\title{
PENGARUH MODEL DISCOVERY LEARNING TERHADAP HASIL BELAJAR PESERTA DIDIK PADA MATA PELAJARAN IPS TERPADU MTS MIFTAHUL ULUM BANTAL
}

\author{
Kiptiatul Hasanah', Nursalam², \\ ${ }^{12}$ STKIP PGRI Situbondo Jawa Timur Indonesia \\ Email: hasanahkiptiatul18@gmail.com
}

\begin{abstract}
Abstrak
Abstract: This study aims to determine the effect of the discovery learning model on student learning outcomes in the Integrated Social Studies subject, subject matter of demand and offerings for class VII A at Mts Miftahul Ulum Bantal even semester of the 2019-2020 school year. This study used a one-shot case study design. The population in this study is class VII A Mts Miftahul Ulum Bantal which uses one class with a total of 30 students. Data collection in this study was carried out using observation, interviews, and documentation and then analyzed by using the t-test. The results of the analysis show that tcount> ttable or 3,814>2,045. It can be concluded that there is an average difference between the pretest and posttest learning outcomes, which means that there is an effect of the discovery learning model on student learning outcomes in Integrated Social Studies subjects class VII A at Mts Miftahul Ulum Bantal. even semester of the 2019-2020 school year.
\end{abstract}

Keywords: Discovery Learning, Learning Outcomes, Student

\begin{abstract}
Abstrak : Penelitian ini bertujuan untuk mengetahui pengaruh model discovery learning terhadap hasil belajar peserta didik pada mata pelajaran IPS Terpadu materi permintaan dan penawran kelas VII A di Mts Miftahul Ulum Bantal semester genap tahun pelajaran 2019-2020. Penelitian ini menggunakan penelitian desain one-shot case study. Populasi dalam penelitian ini yaitu kelas VII A Mts Miftahul Ulum Bantal yang menggunakan satu kelas dengan jumlah 30 peserta didik. Pengumpulan data dalam penelitian ini dilakukan dengan menggunakan observasi, wawancara, dan dokumentasi dan selanjutnya dianalisis dengan uji t-test. Hasil analisis menunjukkan bahwa $t_{\text {hitung }}>t_{\text {tabel }}$ atau 3,814 $>2,045$.dapat disimpulkan ada perbedaan rata-rata antara hasil belajar pretest dan posttest yang artinya ada pengaruh model discovery learning terhadap hasil belajar peserta didik pada mata pelajaran IPS Terpadu kelas VII A di Mts Miftahul Ulum Bantal semester genap tahun pelajaran 2019-2020.
\end{abstract}

Kata Kunci: Discovery Learning, Hasil Belajar, Peserta Didik

\section{PENDAHULUAN}

Hasil belajar merupakan kemampuan peserta didik setelah mendapatkan pengalaman belajar, kegiatan belajar mengajar sasarannya adalah hasil belajar, jika cara belajarnya baik maka hasil belajarnya akan baik. Menurut Prasetyo Tri Sakti (2020). Hasil belajar merupakan kemampuan atau ketercapaian yang di peroleh 
peserta didik setelah melakukan proses belajar, hasil yang di peroleh melalui proses belajar dapat berupa pengetahuan, sikap, ataupun keterampilan sesuai yang di pelajarinya. Hasil belajar yang di lakukan dalam penelitian ini merupakan hasil belajar yang di deskripsikan dalam ranah kognitif atau pengetahuan peserta didik. Menurut Nurdiana (2019) tujuan mata pelajaran IPS adalah mengembangkan potensi peserta didik, potensi yang di kembangkan oleh aspek kognitif ialah agar peserta didik dapat memiliki pemahaman yang baru tentang masalah sosial yang terjadi. Hasil belajar merupakan salah satu faktor untuk menentukan proses belajar, kriteria keberhasilan belajar peserta didik dapat di lihat dari seberapa banyak materi yang dikuasi oleh peserta didik (Darmadi \& Setiawan, 2020).

Keberhasilan proses pembelajaran peserta didik dapat di lihat dari hasil belajar, Haderiah (2019) menyampaikan kriteria keberhasilan proses belajar mengajar di tandai dengan terjadinya peningkatan perubahan tingkah laku dan peningkatan perubahan pengetahuan pada diri individu yang belajar, untuk mencapai kriteria keberhasilan proses belajar ini tugas atau peran guru untuk memilih dan menggunakan model yang kreatif untuk meningkatkan keberhasilan proses belajar.

Berdasarkan observasi yang di lakukan oleh peneliti terhadap guru mata pelajaran IPS Terpadu khususnya peserta didik dikelas VII A pada pelajaran IPS Terpadu peserta didik masih cenderung kurang aktif dan lambat memberikan jawaban atau timbal balik, seingga hasil belajar peserta didik masih rendah dalam mengikuti pembelajaran, maka hal ini dapat dilihat dari nilai ulangan harian yang masih dibawah kriteria ketuntasan minimal (KKM) dengan nilai dibawah 70 . Sehingga diperlukan suatu tindakan yang di lakukan untuk menjawab permasalahan di kelas, salah satunya adalah dengan cara menerapkan model pembelajaran yang tepat yaitu menerapkan model discovery learning, sehingga memperlihatkan bahwa ketercapaian rata-rata mencapai ketuntasan belajar minimal yaitu 75. Pembelajaran IPS Terpadu hakikatnya merupakan pembelajaran yang memungkinkan peserta didik mampu mencari, menggali, dan menemukan konsep serta prinsip. Maka di perlukan adanya suatu tindakan yang di lakukan untuk menjawab permasalahan di kelas,. Hasil belajar peserta didik hal yang perlu di perhatikan adalah proses belajar mengajar, banyak model pembelajaran yang akan meningkatkan hasil belajar yang 
di terapkan terhadap peserta didik, oleh karena itu di butuhkan model pembelajaran yang cocok untuk meningkatkan hasil belajar peserta didik.

Kikot et al., (2012) Hasil belajar peserta didik dapat dikatakan berkualitas, yaitu dengan cara menghasilkan proses pembelajaran yang berkualitas tenaga pendidik harus benar-benar menerapkan model pembelajaran yang sesuai dengan kebutuhan peserta didik dikelas, ketidak sesuaian model pembelajaran dapat menurunkan kualitas proses pembelajaran itu sendiri, dengan demikian peningkatan hasil belajar peserta didik dapat dilaksanakan dengan adanya penggunaan model pembelajaran yang tepat oleh guru. Dengan demikian penelitian ini menggunakan model pembelajaran discovery learning untuk meningkatkan hasil belajar peserta didik (Mardiah, 2017). Oleh karena itu untuk melakukan perubahan dalam proses hasil belajar peserta didik agar lebih aktif yaitu dengan menggunakan model discovery learning, tidak setiap pembelajaran bisa menggunakan model discovery learning, pada materi permintaan dan penawaran dengan melakukan model discovery learning partisipasi dari setiap peserta didik lebih aktif.

Model discovery learning merupakan model pembelajaran yang menekankan guru untuk memberikan masalah pada peserta didik kemudian peserta didik di suruh memecahkan masalah tersebut melalui melakukan percobaan, megumpulkan data, menganalisis, dan mengambil kesimpulan. model pembelajaran ini menitik beratkan pada aktifitas peserta didik dalam belajar. dimana peserta didik harus mampu membedakan sesuatu konsep atau prinsip. Proses mental tersebut antara lain mengamati, mencerna, mengerti, menggolonggolongkan, membuat dugaan, menjelaskan, mengukur, membuat kesimpulan untuk memecahkan masalah (Anggoro, 2016).

Model discovery learning menekankan kepada pengamatan belajar aktif yang berpusat kepada peserta didik, menemukan ide-ide sendiri. Model discovery learning juga menekankan pola dasar melakukan pengamatan, merumuskan masalah, merumuskan hipotesis, dan mengumpulkan data, mengolah data, menganalisis data, menarik kesimpulan dan mengkomunikasikan. Model pembelajaran ini menekankan guru untuk memberikan masalah pada peserta didik kemudian peserta didik disuruh untuk memecahkan masalah tersebut (Yulisna \& 
Sartiman, 2019). Model discovery learning merupakan salah satu model pembelajaran yang mengajak peserta didik untuk lebih aktif dalam membangun pengetahuannya (Setyaningrum et al., 2018). Penemuan (discovery) merupakan suatu model pembelajaran yang di kembangkan berdasarkan pandangan konstruktivisme, salah satu model pembelajaran yang dapat mengatasi permasalahan tersebut yaitu model discovery learning.

Menurut (Surur \& Oktavia, 2019) model discovery learning merupakan model pembelajaran yang dilakukan melalui kegiatan percobaan sehingga peserta didik memperoleh pengetahuan yang sebelumnya belum diketahui tidak melalui pemberitahuan sebagian atau seluruhnya ditemukan sendiri, untuk memberikan kesempatan kepada peserta didik untuk menemukan informasi yang berupa konsepkonsep dan prinsip-prinsip dalam suatu proses mental. Model discovery learning lebih menekankan di temukannya pemahaman konsep yang sebelumnya belum di ketahui, pada model discovery learning guru berperan sebagai pembimbing dengan memberikan kesempatan untuk belajar lebih aktif di dalam kelas sebagaimana pendapat guru harus dapat membimbing mengarahkan peserta didik dengan kegiatan belajar sesuai dengan tujuannya (Indira \& Sanova, 2019). Model discovery learning mempunyai kelemahan/kekurangan yaitu, menghabiskan banyak waktu karena guru harus menjadi fasilitator, motivator dan sekaligus pembimbing.

Menurut Salmi (2019) langkah-langkah pembelajaran dengan model discovery learning yaitu :

1. memberikan stimulus kepada peserta didik,

2. mengidentifikasi permasalahan yang relevan dengan bahan pelajaran, merumuskan masalah kemudian menentukan jawaban sementara (hipotesis),

3. membagi peserta didik menjadi beberapa kelompok untuk melakukan diskusi,

4. memfasilitasi peserta didik dalam kegiatan pengumpulan data, kemudian mengolahnya untuk membuktikan jawaban sementara (hipotesis),

5. mengarahkan peserta didik untuk menarik kesimpulan berdasarkan hasil pengamatannya, dan

6. mengarahkan peserta didik untuk mengomunikasikan hasil temuannya.

Made (2014) menguraikan model pembelajaran discovery learning memiliki beberapa kelebihan. yaitu: 
1. Menambah pengalaman peserta didikdalam belajar

2. Memberikan kesempatan kepada peserta didik untuk lebih dekat lagi dengan sumber pengetahuan selain buku

3. Menggali kreatifitas peserta didik

4. Mampu meningkatkan rasa percaya diri pada peserta didik

5. Meningkatkan kerjasama antar peserta didik.

\section{METODE PENELITIAN}

Rancangan yang di gunakan dalam penelitian ini adalah penelitian kuantitatif, Metode ini menggunakan metodo pre-eksperimental design bentuk design yang di gunakan dalam penelitian ini adalah desain one-shot case study

Tabel Desain One-Shot Case Study

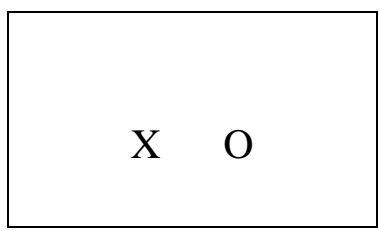

yaitu dengan desain terdapat satu kelompok atau menggunakan satu kelas diberi treatment/perlakuan dan selanjutnya di observasi hasilnya. Desain ini di lakukan dengan membandingkan hasil pretest dan posttest pada kelompok yang di uji cobakan.

Teknik penentuan lokasi ini dilakukan secara sengaja (purposive sampling area) dalam penelitian ini lokasi yang di tetaptkan oleh peneliti adalah di Mts Miftahul Ulum Bantal. Teknik penentuan responden populasi yang digunakan dalam penelitian ini adalah merujuk pada peserta didik kelas VII A Mts Miftahul Ulum Bantal, untuk penentuan sampel dengan pertimbangan tertentu. Di tentukan di kelas VII A sebanyak 30 sampel dengan menggunakan model discovery learning. Metode yang digunakan penulis dalam penelitian ini yaitu: observsi, dokumentasi, dan interview atau wawancara. Analisa data dengan menggunakan uji t-test.

\section{HASIL DAN PEMBAHASAN}

\section{Hasil}

Hasil dan pembahasan pada penelitian ini akan di uraikan sebagai berikut : 
Tabel 4.2 ringkasan hasil statistik dengan menggunakan SPSS 25.0

\section{Paired Samples Statistics}

\begin{tabular}{lrr|r|r|r} 
& & Mean & N & \multicolumn{1}{c|}{ Std. Deviation } & \multicolumn{1}{c}{ Std. Error Mean } \\
\hline \multirow{2}{*}{ Pair 1 } & Pre Test & 78,30 & 30 & 6,824 & 1,246 \\
\cline { 2 - 7 } & Pos Test & 83,67 & 30 & 8,503 & 1,552 \\
\hline
\end{tabular}

Pada tabel di atas diperlihatkan ringkasan hasil statistik dari kedua sample yang di teliti yaitu pretest dan posttest. Untuk nilai pretest diperoleh dengan ratarata hasil belajar atau mean sebesar 78,30, sedangkan niali posttest diperoleh nilai rata-rata hasil belajar sebesar 83,67 . Jumlah respendon atau peserta didik yang digunakan sebagai sampel sebanyak 30 peserta didik, untuk nilai Std. Deviation (standar deviasi) pada nilai pretest sebesar 6,824 dan posttest sebesar 8,503. Selanjutnya Std. Error mean untuk nilai pretest 1,246 dan untuk nilai posttest sebesar 1,552 .

Nilai rata-rata hasil belajar pada pretest 78,30 < Posttest 83,67, maka dapat diartikan secara deskriptif ada perbedaan rata-rata hasil belajar peserta didik antara pretest dan posttest. Selanjutnya untuk membuktikan apakah perbedaan benerbenar nyata nyata (signifikan) perlu memaparkan hasil uji paired sampel t-test yang terdapat pada tabel berikut.

Hasil uji korelasi menggunakan SPSS 25.0

\section{Paired Samples Correlations}

\begin{tabular}{rrr|r|r} 
& & \multicolumn{1}{c|}{ Correlation } & \multicolumn{2}{c}{ Sig. } \\
\hline Pair 1 & Pre Test \& Pos Test & 30 &, 512 &, 004 \\
\hline
\end{tabular}

Berdasarkan penghitungan data tersebut menunnjukkan hasil korelasi (correlation) sebesar 0,512 dengan nilai signifikansi (Sig). Sebesar 0,004 < probabilitas 0,05 maka dapat di katakan ada hubungan antara pretest dan posttes

Hasil perhitungan uji t-test dengan menggunakan SPSS 25.0

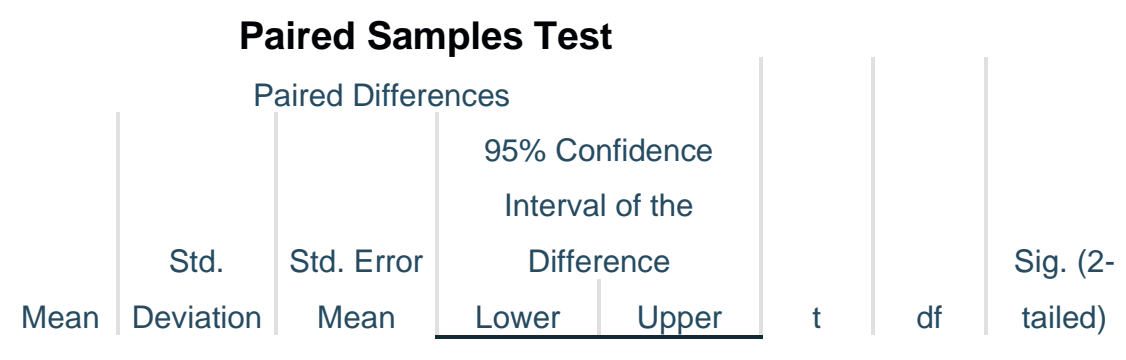




\begin{tabular}{|c|c|c|c|c|c|c|c|c|c|}
\hline $\begin{array}{l}\text { Pair } \\
1\end{array}$ & $\begin{array}{l}\text { Pre Test - } \\
\text { Pos Test }\end{array}$ & $-5,367$ & 7,708 & 1,407 & $-8,245$ & $-2,488$ & $\begin{array}{r}- \\
3,814\end{array}$ & 29 & ,001 \\
\hline
\end{tabular}

\section{a. Menentuakan hipotesis}

$\mathrm{H}_{\mathrm{a}}$ : Ada pengaruh model discovery learning terhadap hasil belajar peserta didik pada mata pelajaran IPS Terpadu kelas VII A di MTS Miftahul Ulum Bantal semester genap tahun peajaran 2019-2020

\section{b. Menentukan dasar pengambilan keputusan}

Berdasarkan nilai signifikan untuk menentukan dasar pengambilan keputusan yaitu

Jika nilai sig. (2-tailed) $<0,05$ maka $\mathrm{H}_{\mathrm{O}}$ di tolak dan $\mathrm{H}_{\mathrm{a}}$ di terima Jika nilai sig. (2-tailed) $>0,05$ maka $\mathrm{H}_{\mathrm{O}}$ di terima dan $\mathrm{H}_{\mathrm{a}}$ di tolak

Berdasarkan tabel 4.3 paired sample t-test di atas di ketahui nilai sig. (2tailed) adalah sebesar 0,001 $<0,05$, maka $\mathrm{Ho}_{\mathrm{O}}$ di tolak dan $\mathrm{H}_{\mathrm{a}}$ di terima. Sehingga dapat di simpulkan bahwa ada perbedaan rata-rata antara hasil belajar nilai pretest dan posttest, sehingga bisa di katakan ada pengaruh model discovery learning terhadap hasil belajar peserta didik pada mata pelajaran IPS Terpadu kelas VII A di MTS Miftahul Ulum Bantal semester genap tahun pelajaran 2019-2020.

Selain membandingkan sig 0,05 selanjutnya membandingkan antara nilai $t_{\text {hitung }}$ dengan $t_{\text {tabel. }}$. Berdasarkan keputusannya ialah,

Jika niai thitung $>t_{\text {tabel}}$, maka $\mathrm{H}_{\mathrm{o}}$ di tolak dan $\mathrm{H}_{\mathrm{a}}$ di terima

Jika nilai thitung $<\mathrm{t}_{\text {tabel, }}$ maka $\mathrm{H}_{\mathrm{o}}$ di terima dan $\mathrm{H}_{\mathrm{a}}$ di tolak.

Berdasarkan pada tabel 4.3 paired sample t-tes di atas di ketahui thitung bernilai negatif $-3,814$, namun jika thitung bernilai negatif ini di sebabkan karena nilai rata-rata hasil belajar pretest lebih rendah dari pada rata-rata nilai hasil belajar posttest, maka dalam konteks seperti ini di katakan nilai thitung bermakna positif, sehingga nilai thitung menjadi 3,814.

Dimana mencari nilai tabel di cari berdasarkan nilai df (derajat kebebasan) dan nilai sig. $(\alpha / 2)$ dari tabel di atas di ketahui nilai df sebesar 29 dan nilai $0,05 / 2$ $=0,025$ nilai $\mathrm{t}$ tabel sebesar 2,045, nilai tersebut dapat di jadikan sebagai acuan dalam mencari nilai $t_{\text {tabel }}$ pada distribusi nilai tabel statistik, (nilai $r$ tabel terlampir pada halaman lampiran) 
Dengan demikian nilai $\mathrm{t}_{\text {hitung }} 3,814>\mathrm{t}_{\text {tabel }} 2,045$, maka dapat di simpulkan bahwa dasar pengambilan keputusan di atas $\mathrm{H}_{\mathrm{O}}$ di tolak dan $\mathrm{H}_{\mathrm{a}}$ di terima, sehingga dapat di simpulkan bahwa ada perbedaan rata-rata antara hasil belajar pretest dan posttest yang artinya ada pengaruh model discovery learning terhadap hasil belajar peserta didik pada mata pelajaran IPS Terpadu kelas VII A di MTS Miftahul Ulum Bantal semester genap tahun pelajaran 2019-2020.

\section{Pembahasan}

Berdasarkan hasil analisis data yang di lakukan di Mts Miftahul Ulum Bantal kelas VII A pada semester genap tahun pelajaran 2019-2020 dengan menggunakan model discovery learning pada materi permintaan dan penawaran yang telah di lakukan menunnjukkan bahwa hasil belajar peserta didik meningkat dari nilai pretest rata-rata 78,30 meningkat dengan nilai posttest rata-rata sebesar 83,67 , dan selanjutnya hasil belajar peserta didik dapat meningkat di perkirakan karena adanya pengaruh model discovery learning, hal ini di tunjukkan ketika proses pembelajaran materi permintaan dan penawaran berlangsung peserta didik mampu mencari dan menyelidiki, sehingga peserta didik dapat menemukan sendiri pengetahuannya faktor yang menunjukkan hasl belajar meningkat di karenakan besarnya usaha yang dicurahkan oleh peserta didik untuk mencapai hasil belajar, intelegensi atau penguasaan awal peserta didik tentang materi yang akan di pelajari, dan adanya kesempatan yang di berikan kepada peserta didik yang artinya guru perlu membuat rancangan pembelajaran yang memungkinkan peserta didik dapat bereksplorasi bebas terhadap lingkungan.

Setelah menganalisis data dan pengujian hipotesis hasil di atas yang telah di lakukan dengan pengukuran menggunakan SPSS 25.0 di peroleh nilai sig. (2tailed) adalah sebesar $0,001<0,05$, maka $\mathrm{H}_{\mathrm{O}}$ di tolak dan $\mathrm{H}_{\mathrm{a}}$ di terima. Sehingga dapat di simpulkan bahwa ada perbedaan rata-rata antara hasil belajar nilai pretest dan posttest, dan bisa di katakan ada pengaruh model discovery learning terhadap hasil belajar peserta didik pada mata pelajaran IPS Terpadu kelas VII A di Mts Miftahul Ulum Bantal semester genap tahun pelajaran 2019-2020. Penelitian ini sejalan dengan penelitian Mega Lestari, Maskun dan Yustina Sri Ekwandari hasil analisis data dan pembahasan yang telah dilakukan dalam tulisannya, dapat disimpulkan bahwa model discovery learning berpengaruh kuat terhadap hasil 
belajar kognitif peserta didik (Lestari Mega, 2015) dan juga sejalan dengan hasil penelitian yang di lakukan oleh Dipo Susilo, Suib Awrus dan Zubaidah hasil analisis data dan pembahasan dapat di simpulkan bahwa penggunaan model discovery learning berpengaruh terhadap hasil belajar peserta didik (Susilo Dipo, 2019).

\section{SIMPULAN}

Berdasarkan hasil penelitian yang di landaskan oleh teori dan di dukung dengan hasil analisis data yang di laksanakan mengenai pembelajaran IPS Terpadu dengan menerapkan model discovery learning terhadap hasil belajar peserta didik di MTs Miftahul Ulum Bantal bahwa ada pengaruh signifikan model discovery learning terhadap hasil belajar peserta didik

Hal ini disebabkan karena dalam proses pembelajaran dengan model discovery learning banyak melibatkan peserta didik dalam kegiatan mengajar. Demikian model discovery learning dapat menjadi salah satu tujuan bagi para guru dalam meningkatkan hasil belajar peserta didik.

\section{DAFTAR RUJUKAN}

Bambang Sri Anggoro. (2016). Meningkatkan Kemampuan Generalisasi Matematis Melalui Discovery Learning dan Model Pembelajaran Peer Led Guided Inquiry. 7(1), 11-20.

Darmadi, I. W., \& Setiawan, R. (2020). Upaya Peningkatan Hasil Belajar Fisika Peserta Didik melalui Penerapan Model Pembelajaran Berbasis Jasa Layanan di SMA Labschool Untad Palu. 7(3), 32-37.

Haderiah. (2019). Upaya Meningkatkan Hasil Belajar Dan Kemampuan Gerak Dasar Permainan Rounders Melalui Strategi Pembelajaran Berpasangan Siswa Kelas V SD Negeri 112 Pacciro. 2.

Indira, T., \& Sanova, Y. (2019). Peningkatan Kemampuan Pemecahan Masalah pada Materi Persamaan Garis Singgung Lingkaran melalui Pembelajaran Discovery Learning. 2(November), 69-76.

Kikot, R., Kendek, Y., \& Werdhiana, I. K. (2012). Pengaruh Model Pembelajaran 
Kooperatif Tipe Pair Checks terhadap Hasil Belajar Fisika Siswa Kelas VIII SMP Negeri Model Terpadu Madani. 6(3), 3-6.

Lestari Mega, M. \& E. (2015). Pengaruh MOdel Discovery Learning Teradap Hasil Belajar Siswa Pada Mata Pelajaran Sejarah. 1.

Mardiah. (2017). Penggunaan metode pembelajaran dalam peningkatan hasil belajar siswa. STUDIA DIDAKTIKA: Jurnal Ilmiah Bidang Pendidikan, 11(1), 9-16.

Nurdiana. (2019). Upaya Meningkatkan Hasil Belajar IPS Melalui Penerapan Metode Problem Solving. 3(1), 1-6.

Prasetyo Tri Sakti, dkk. (2020). Deskripsi Hasil Belajar Matematika Siswa Kelas VII SMP Negeri 1 Bintan Pada Materi Operasi Bentuk Aljabar Dengan Menggunakan Model Pembelajaran Treffinger. 582-587.

Putrayasa Made, dkk. (2014). Pengaruh Model Pembelajaran Discovery Learning dan Minat belajar Terhadap Hasil Belajar IPA Siswa.

Salmi. (2019). Penerapan Model Pembelajaran Discovery Learning Dalam Meningkatkan Hasil Belajar Ekonomi Peserta Didik Kelas XII IPS.2 SMA Negeri 13 Palembang.

Setyaningrum, V. F., Hendikawati, P., \& Nugroho, S. (2018). Peningkatan Pemahaman Konsep Dan Kerja Sama Siswa Kelas X Melalui Model Discovery Learning. 1, 810-813.

Surur \& Oktavia. (2019). Pengaruh Model Pembelajaran Discovery Learning Terhadap Pemahaman Konsep Matematika. 6(1), 11-18.

Susilo Dipo, D. (2019). Pengaruh Model Pembelajaran Discovery Learning Terhadap Hasil Belajar Seni Budaya Materi Mseni Rupa Siswa Kelas VII SMP Negeri 30 Padang.

Yulisna \& Sartiman. (2019). Discovery Learning: Pengaruhnya Terhadap Hasil Belajar Discovery Learning: The Influence To Learning Outcome. 02(1), 123-129. 